EDITOR

Roger Jones, DM, FRCP, FRCGP, FMedSci London

DEPUTY EDITOR

Alec Logan, FRCGP

Motherwell

JOURNAL MANAGER

Catharine Hull

SENIOR ASSISTANT EDITOR

Erika Niesner

ASSISTANT EDITOR

Moira Davies-Cinar

EDITORIAL ASSISTANT

Tania Marszalek

ADVERTISING EXECUTIVE

Brenda Laurent

EDITORIAL BOARD

Richard Baker, MD, FRCGP

Leicester

Stephen Barclay, MD, FRCGP, DRCOG

Cambridge

Chris Butler, MD, MRCGP

Cardiff

Kath Checkland, PhD, MRCGP

Manchester

Mark Gabbay, MD, FRCGP

Liverpool

Clare Gerada, MBE, FRCGP, MRCPsych

London

Murray Lough, MD, FRCGP

Glasgow

David Mant, MD, FRCGP, FMedSci

Oxford

Tim Peters, MSc, PhD, CStat, FFPH

Bristol

Chris Salisbury, MD, FRCGP

Bristol

John Sandars, MSc, MD, FRCGP, MRCP

Leeds

Mark Shapley, FRCGP, DCH, DRCOG

Newcastle-under-Lyme

Niroshan Siriwardena, MMedSci, PhD,

FRCGP

Lincoln

Theo Verheij, MD, PhD, MRCGP

Utrecht, The Netherlands

Sue Wilson, BA, PhD, PGA

Birmingham

2009 impact factor: 2.442

EDITORIAL OFFICE

1 Bow Churchyard, London, EC4M 9DQ

(Tel: 0203188 7400, Fax: 0203188 7401).

E-mail: journal@rcgp.org.uk

http://www.rcgp.org.uk/bjgp

PUBLISHED BY

The Royal College of General Practitioners,

1 Bow Churchyard, London, EC4M 9DQ.

Registered charity number 223106. The BJGP is

published by the RCGP, but has complete

editorial independence. Opinions expressed in the

BJGP should not be taken to represent the policy

of the RCGP unless this is specifically stated.

No endorsement of any advertisement is implied or intended by the RCGP.

PRINTED IN GREAT BRITAIN BY

HPM Limited, Prime House, Park 2000, Heighington

Lane Business Park

Newton Aycliffe, Co. Durham DL5 6AR.

Printed on $100 \%$ recycled paper

ISSN 0960-1643 (Print)

ISSN 1478-5242 (Online)

\title{
November Focus
}

\section{SHAPING THE FUTURE}

Our major themes this month are education and training, and the care of pregnant women, with many of the articles in the Journal both questioning and illuminating core roles and values of general practice and primary care.

Tomorrow's doctors are likely to be taught in a much more resource-aware higher education environment, where universities will be looking for ways to deliver new curricula at lower costs, while students will be asked to pay more and will have higher expectations of their teachers. Postgraduate training will, increasingly, need to prepare GPs for new roles in response to changes in healthcare systems, health technologies, and in the demographics and expectations of the population. John Rees and Anne Stephenson consider some of these challenges in relation to undergraduate education in the wake of recent guidance from the GMC, while a group of papers examines the problems of selecting and distributing general practice trainees in ways which will meet the demands of a rapidly changing medical landscape, one in which an inverse care law still operates in relation to training and deprivation. Tsimtsiou and colleagues look at the way that a formal master's programme in primary care can contribute to this picture, while papers by Edgcumbe from the UK and Kjeldmand and Holmström from Sweden remind us of the legacy of Michael Balint and the place of Balint groups in supporting primary care clinicians in these turbulent times. Edgcumbe reminds us, too, of the still unresolved divide between primary and secondary care, a topic on which Balint's views, expressed almost 50 years ago, still have resonance.

Maruthappu and colleagues write perceptively about the possible impacts of the proposed changes to the NHS, recognising the opportunity for primary and secondary care to work more closely together, but also sounding a warning note about the crucial role of training, and the risks to delivering adequate training in a system driven by the imperative to deliver services more cheaply. Training capacity is required not only for the increasingly complex clinical work of primary care, as comorbidity becomes the norm and the focus shifts more and more from the outpatient clinic to the surgery, but for the new roles - needs assessment, service design, commissioning, and quality assurance, among others - that a 'new' NHS will demand.

David Jewell's powerful editorial on the need for GPs to remain engaged with antenatal and postnatal care draws on three persuasive qualitative studies on diabetes, haemoglobinopathy, and depression in and after pregnancy. Not only does he make a strong, I think unanswerable, case for the continued and close involvement of GPs in maternity care, but he raises fundamental questions about the generalist role, the dangers of fragmentation and de-skilling, and the serious damage that can be done to doctor-patient relationships and patients' health outcomes. Jewell doesn't quite say it, but the fact is doctors have diagnostic and management skills that are not held by midwives, and making it difficult for pregnant women to access them is just as dangerous as letting GPs become unskilled in the recognition and management of obstetric complications. All of which, of course, has significant training and revalidation implications.

If all this is a bit much, make a strong cup of tea and settle down to lan McGilchrist's review of James Le Fanu's recent book Why us? How science rediscovered the mystery of ourselves. Probably overshadowed at the time of publication by Richard Dawkins' The God delusion, Le Fanu's account of the failures of neuroscience and genetics to explain very much at all, and his rediscovery of the work of Rupert Sheldrake and his theory of morphic resonance, ${ }^{2}$ are provocative and strangely appealing, perhaps because they are a welcome relief from the strident hyper-rationalism that we have become used to seeing in the bestseller charts. I couldn't help making whimsical connections with the essence of the GP - at its best considerably greater than the sum of its parts, suffused with motives and impulses that may not readily be discerned by reforming politicians and managers, easily dismantled, and extremely difficult to rebuild.

\section{Roger Jones}

Editor

1. Balint M. The doctor, his patient and the illness. 2nd edn. Edinburgh: Churchill Livingstone, 1963.

2. Sheldrake R. Morphic resonance: the nature of formative causation. Maine, NE: Park Street Press, 2009.

DOI: 10.3399/bjgp10X538886

(c) British Journal of General Practice 2010; 60: 793-872. 